\begin{tabular}{c|c|c|} 
Dinamika Journal, Vol. 1 No.2, 2019 \\
ISSN ONLINE : 2686-2158 \\
Journal Homepage $:$ http://jurnal.lppm.unsoed.ac.id/ojs/index.php/dinamika
\end{tabular}

\title{
PENINGKATAN PENGETAHUAN PEMBERIAN MAKAN BAYI BAWAH DUA \\ TAHUN PADA KADER POSYANDU DESA KARANGSALAM KIDUL KECAMATAN KEDUNGBANTENG KABUPATEN BANYUMAS
}

\author{
Ibnu Zaki ${ }^{1, *}$, Afina Rachma Sulistyaning ${ }^{1}$, Farida ${ }^{1}$ \\ ${ }^{1}$ Program Studi Ilmu Gizi, Fakultas Ilmu-ilmu Kesehatan, Universitas Jenderal Soedirman \\ *Corresponding author: ibnu.zaki@unsoed.ac.id
}

Received 2019; Accepted 2019; Available online 2019

\begin{abstract}
Abstrak
Masalah gizi pada bayi muncul diakibatkan kurangnya pengetahuan ibu terkait pemberian makan bayi bawah dua tahun (Baduta). Kader posyandu merupakan kerabat dekat ibu baduta sehingga kader dapat menjangkau ibu baduta di wilayahnya. Selain itu kader merupakan kelompok pendidik sebaya yang potensial dalam upaya peningkatan pengetahuan ibu baduta. Kegiatan ini bertujuan untuk membekali para kader dengan meningkatkan pengetahuan terhadap pemberian makan bayi. Metode yang digunakan adalah pelatihan disertai simulasi. Analisis data menggunakan uji Paired T-test. Hasil pelatihan menunjukan adanya peningkatan rata-rata skor pengetahuan kader dari $15.71 \pm 1.7$ menjadi $16.33 \pm 1.7$ setelah pelatihan. Pelatihan ini meningkatkan pengetahuan responden terkait pemberian makan pada baduta.
\end{abstract}

Kata kunci: Baduta, pemberian makan baduta, pelatihan, simulasi

\begin{abstract}
Nutritional problems in infants arose due to a lack of maternal knowledge relatedtofeeding management to infants under two years-old (Baduta). The posyandu cadres are close relatives of Baduta's mother, thus, they can reach out to Baduta's mother in their area. In addition, cadres are a group of potential peer educators in an effort to increase the knowledge of Baduta's mother. This activity is aiming to equip cadres by increasing their knowledge of infant feeding. The method used was training with simulation. The data were analysed using Paired T-test. The results of the training showed a significant increase in the average cadre knowledge score from $15.71 \pm 1.7$ to $16.33 \pm 1.7$ after the training. This training increased the respondent's knowledge related to feeding to Baduta.
\end{abstract}

Keywords: under two years, toddler, training, simulation.

\section{PENDAHULUAN}

Masalah gizi kurang pada Bayi masih menjadi masalah kesehatan utama yang dihadapi oleh Kabupaten Banyumas. Berdasar laporan Dinas Kesehatan Kabupaten Banyumas menunjukan Jumlah Berat Badan Lahir Rendah (BBLR) kurang dari 2500 g sebesar 5,2\%, prevalensi balita gizi buruk sebesar $0,27 \%$, gizi kurang $(\mathrm{BB} / \mathrm{U}) 12,13 \%$, kurus $(\mathrm{BB} / \mathrm{TB})$ sebesar 4,6\% terutama angka stunting atau pendek (TB/U) 29,79\%, (Banyumas, 2016).

I. Zaki et al., 2019. Peningkatan Pengetahuan Pemberian Makan Bayi Bawah Dua 
Bahkan tingginya angka stunting tersebut menjadi dasar oleh Kementerian Kesehatan Republik Indonesia (Kemenkes RI) untuk mengkategorikan Kabupaten Banyumas sebagai lokasi fokus penurunan masalah gizi.

Penyebab utama masalah gizi kurang pada bayi dan balita ialah karenakonsumsi gizi yang tidak mencukupi kebutuhan. Hal ini disebabkan oleh beberapa faktor diantaranya tingkat pemahaman ibu bayi tentang menu makanan gizi seimbangdan budaya masyarakat berkaitan dengan pemberianmakanan terutama pada masa bayi (Sunita, 2009). Sebagian masyarakat masih mempercayai mitos terkait makanan tertentu. Pada usia bayi dan balita anak tidak diperbolehkan makan makanan tertentu terutama pada usia pemberian ASI (usia dua tahun). Makanan seperti Telur, ikan, kacang-kacangan terkadang dipercaya akan memberikan dampak yang kurang baik bagi pertumbuhan dan perkembangan anak (Ginting, 1997).

Permasalah gizi kurang sebenarnya dapat dikurangi jika dilakukan upaya sejak dini dengan memberikan pendidikan gizi tentang jenis dan manfaat zat-zat yang terkandung dalam tiap makanan, terutama dimasa pemberian ASI. Selain itu dengan upaya pendidikan gizi pandangan dan budaya masyarakat terkait mitos pantangan makan tertentu pada masa pemberian ASI dapat dikurangi (Jus' at, 1992). Permasalahan pelaksanaan pendidikan gizi di masyarakat muncul karena daya jangkau pelayanan kesehatan kepada masyarakat oleh petugas kesehatan kurang. Sehingga dibutuhkan tenaga yang lebih banyak sehingga dapat menjangkau sampai tingkat rumah tangga.

Posyandu dapat dijadikan ujung tombak dan menjadi solusi dalam memberikan pendidikan gizi terkait jenis dan manfaat makanan pendamping ASI yang tepat (Nazri et al., 2015). Posyandu sebagai pusat pemberdayaan masyarakat dapat dimanfaatkan untuk memberikan informasi dan pemantauan terhadap tumbuh kembang bayi (RI, 2011). Pelaksana kegiatan posyandu adalah kader kesehatan yang berasal dari masyarakat setempat dan bekerja secara sukarela. Kader memegang peranan yang sangat penting dalam pelaksanaan posyandu di lapangan sehingga keberadaannya sangat vital namun potensial.

Peran kader posyandu sebagai kunci keberhasilan kegiatan posyandu, namun ada beberapa kendala yang selama ini membuat kinerja kader posyandu tidak maksimal. Kendala yang paling sering dihadapi adalah kemampuan kader dalam mentransfer informasi kesehatan kepada ibu-ibu peserta posyandu, dan juga kendala yang berkaitan dengan pemahaman tentang jenis dan manfaat makanan yang baik untuk pendamping ASI (Hernawan et al., 2016). Oleh karena itu Berdasarkan wawancara dengan mitra yang merupakan seorang bidan desa Karangsalam yang menaungi seluruh posyandu yang ada di Desa Karangsalam. Mitra mengeluhkan bahwa sampai saat ini penyegaran kader posyandu yang biasa di lakukan masih berkisar teknik-teknik pengukuran status gizi dan pelaporan. Materi penyegaran kader belum mengarah kepada peningkatan pengetahuan terkait gizi terutama tentang pemberian gizi pada Ibu, Bayi, dan Balita, serta jenis dan manfaat makanan pendamping ASI yang tepat. Hal ini disebabkan keterbatasan waktu dan kapasitas mitra dalam memberikan penyuluhan tersebut (Utami et al., 2015).

Pelatihan pemberian makan pada bayi bagi kader memiliki potensi yang baik. hal ini dikarenakan para kader bisa menjadi pendidik sebaya kepada ibu bayi yang ada di wilayah posyandunya. Kader di harapkan aktif dan saling berbagi pengalaman untuk pemecahan permasalahan yang di hadapi Ibu bayi khususnya cara dan prinsip pemberian makan bayi terutama usia 6-24 bulan sebagai bagian dari upaya program 1000 Hari pertama kehidupan (HPK). Oleh karena itu kegiatan ini bertujuan untuk membekali para kader dengan meningkatkan pengetahuan terhadap pemberian makan bayi. 


\section{METODE PELAKSANAAN}

\section{a. Rancangan, Lokasi, Partisipan, Bahan dan Alat Kegiatan}

Rancangan kegiatan yang digunakan dalam kegiatan ini adalah pelatihan dengan simulasi. Pelaksanaan kegiatan dilakukan di balai Desa Karangsalam Kidul Kecamatan Kedungbanteng Kabupaten Banyumas. Pelaksanaan kegiatan pada bulan Agustus 2019. Sedangkan Khalayak sasaran ialah seluruh kader posyandu Desa Karangsalam Kidul sejumlah 24 orang. Materi yang disampaikan meliputi cara dan prinsip pemberian makan bayi bawah dua tahu (Baduta) yang dibagi berdasarkan kelompok usia yaitu usia 6-9 bulan, 9-12 bulan, 12-24 bulan. Simulasi yang dilakukan menggunakan media bantu film edukasi. Film yang ditayang merupakan film edukatif yang di susun oleh tim pelaksana kegiatan. Film edukatif yang disimulasikan menceritakan tentang pemberian makan yang di lengkapi dengan contoh-contoh bahan makanan, makanan yang telah diolah dan diakhir tayangan adalah demo membuat menu untuk pemberian makan bayi.

\section{b. Metode Pelaksanaan Kegiatan}

Tahapan kegiatan dibagi menjadi dua kegiatan yaitu sosialisasi kegiatan, dan pelatihan disertai simulasi. Kegiatan pertama diawali dengan sosialisasi kegiatan yaitu mengkomunikasikan rencana kegiatan pelatihan kepada pihak terkait yaitu Kepala Desa, Ketua Kader Posyandu, Bidan Desa Karangsalam Kidul, Kepala Puskesmas Kedungbanteng dan Petugas Gizi Puskesmas Kedungbanteng. Kegiatan kedua dilanjutkan dengan pelatihan. Pelatihan diawali dengan Pretest dan di akhiri dengan Posttest pengetahuan. Materi pelatihan disampaikan oleh tim pengabdi yang memiliki latarbelakang pendidikan ilmu gizi. Setelah pelatihan khalayak sasaran dilakukan Posttest pengetahuan.

\section{c. Metode pengumpulan, Pengolahan dan Analisis data}

Evaluasi kegiatan dilakukan berdasarkan indikator peningkatan pengetahuan kader. Tingkat pengetahuan kader diukur menggunakan instrumen kuesioner pengetahuan yang terdiri dari 20 pertanyaan dengan ceklis benar salah.Analisis data menggunakan pendekatan kuantitatif. Data disajikan dengan pengujian statistik deskriptif. Stastistik deskriptif disajikan dalam bentuk mean \pm standar deviasi (mean \pm SD). Kemudian dilanjutkan menganalisis perbandingan skor pengetahuan antara sebelum dan setelah pelatihan menggunakan uji Paired $t$-T (Dahlan, 2011).

\section{HASIL DAN PEMBAHASAN}

Kegiatan pelatihan dilaksanakan di Balai Desa Karangsalam Kidul Kecamatan Kedungbanteng Kabupaten Banyumas. Kegiatan di awali dengan sosialisasi kegiatan. Kegiatan disambut dengan baik oleh pihak-pihak yang terkait. Sosialisasi dilakukan dengan model rapat koordinasi pihak-pihak terkait. Kemudian penentuan waktu pelaksanaan pelatihan.

Tabel 1. Skor Pengetahuan Sebelum dan Setelah Pelatihan

\begin{tabular}{llccccc}
\hline Variabel & & n & Mean \pm SD & Minimal & Maksimal & p value \\
\hline skor pengetahuan & sebelum pelatihan & 24 & $15.71 \pm 1.7$ & 13 & 18 & \multirow{2}{*}{0,590} \\
& setelah pelatihan & 24 & $16.33 \pm 1.7$ & 13 & 19 & \\
\hline
\end{tabular}


Hasil evaluasi kegiatan berdasarkan indikator pengetahuan responden di paparkan pada tabel 1. Rata-rata skor pengetahuan kader sebelum pelatihan adalah $15.71 \pm 1.7$ sedangkan setelah pelatihan sebesar $16.33 \pm 1.7$ (tabel 1). Hasil yang sama juga disampaikan oleh kegiatan sebelumnya bahwa terjadi peningkatan rata-rata skor pengetahuan kader dari 5.76 menjadi 7.63 setelah diberikan pelatihan dengan metode simulasi (Zaki et al., 2018). Studi pada tahun 2015 juga melaporkan bahwa terjadi peningkatan skor pengetahuan sebesar 2.428 (Lubis, 2015).

Tabel 1 menunjukan bahwa terjadi peningkatan rata-rata skor pengetahuan setelah pelatihan, akan tetapi tidak bermakna secara statistik $(\mathrm{p}=0,590)$. Hal ini tidak sejalan dengan laporan sebelumnya menyatakan bahwa terdapat perbedaan yang signifikan terhadap pengetahuan kader setelah diberikan pelatihan (Lubis, 2015).

Materi pelatihan pemberian makan bayi untuk Baduta dibagi sesuai kelompok umur. Kelompok umur 6-9 bulan, 9-12 bulan, dan 12-24 bulan. Berdasarkan evaluasi kuesioner, persentase kader salah menjawab tertinggi yaitu terkait bentuk makanan yang diberikan untuk bayi usia 6-9 bulan. Pemberian makan pada kelompok usia ini sangat krusial karena pintu gerbang memulai pemberian MP-ASI(Almatsier et al., 2011). Apabila terlalu dini bayi diberikan makan (< 6 bulan) maka beresiko munculnya permasalahan gizi. Studi di Ethiopia melaporkan bahwa pemberian makan sebelum umur 4 tahun menjadi faktor resiko munculnya Stunting (Teshome et al., 2009). Studi di Kota Semarang menunjukan hal yang sama bahwa ada hubungan yang bermakna antara pemberian MP-ASI sejak dini dengan kejadian Stunting (Prihutama et al., 2018). Oleh karena itu perlu lebih ditekankan lagi pengetahuan kader terkait materi pemberian makan bayi usia 6-9 bulan.

\section{KESIMPULAN}

Pelatihan Kader Posyandu di Desa Karangsalam Kidul, Kec. Kedungbanteng, Kab. Banyumas tentang pemberian makanbayi bawah dua tahun meningkatkan pengetahuan kader terkait cara dan prinsip pemberian makanbayi bawah dua tahun. Hal ini diharapkan kader posyandu sebagai khalayak menjadi pendidik sebaya untuk Ibu Bayi dalam upaya pencegahan stunting melalui pemberian makan yang baik. Berdasarkan evaluasi antara pengabdi dan kahalayak bahwa untuk kegiatan selanjutnya perlu dilakukan pembekalan praktek pembuatan makanan bayi secara langsung.

\section{UCAPAN TERIMA KASIH}

Ucapan terima kasih disampaikan kepada Rektor Universitas Jenderal Soedirman melalui Ketua Lembaga Penelitian dan Pengabdian Kepada Masyarakat dengan Skema Penerapan IPTEKS Dipa Universitas Jenderal Soedirman tahun Anggaran 2019. Kepala Desa, Para Kader Posyandu Mawar Desa Karangsalam Kidul, Bidan Desa Karangsalam Kidul, Kepala Puskesmas Kedungbanteng dan Petugas Gizi Puskesmas Kedungbanteng.

\section{DAFTAR PUSTAKA}

Almatsier, S., Soetardjo, S., Soekatri, M. 2011. Gizi seimbang dalam daur kehidupan. Jakarta: Gramedia pustaka utama, pp. 92-103.

Banyumas, D. K. K. 2016. Antinatal Care Terpadu. Dinas Kesehatan Kabupaten Banyumas. Banyumas.

Dahlan, M. S. 2011. Statistik untuk kedokteran dan kesehatan. Penerbit Salemba. 
Ginting, M. 1997. Faktor-faktor yang berhubungan dengan status gizi balita pada empat desa tertinggal dan tidak tertinggal di Kabupaten Pontianak, Propinsi Kalimantan Barat tahun 1995. FKM-UI.

Hernawan, A. D., Marlenywati, M., Ridha, A. 2016. Efektifitas Pelatihan Konseling dan Penyusunan Menu MP-ASI terhadap Keterampilan Kader dalam Mendampingi Ibu. Jurnal Vokasi Kesehatan, 2(1), pp. 69-72.

Jus' at, I. 1992. Faktor-faktor yang Berkaitan dengan Gangguan Pertumbuhan Anak Balita. Gizi Indonesia, 17(1-2).

Lubis, Z. 2015. Pengetahuan dan tindakan kader posyandu dalam pemantauan pertumbuhan anak balita. KEMAS: Jurnal Kesehatan Masyarakat, 11(1), pp. 65-73.

Nazri, C. 2015. Factors influencing mother's participation in Posyandu for improving nutritional status of children under-five in Aceh Utara district, Aceh province, Indonesia', BMC public health. BioMed Central, 16(1), p. 69.

Prihutama, N. Y., Rahmadi, F. A., Hardaningsih, G. 2018. Pemberian makanan pendamping asi dini sebagai faktor risiko kejadian stunting pada anak usia 2-3 tahun. Jurnal Kedokteran Diponegoro, 7(2), pp. 1419-1430.

RI, K. 2011. Buku Panduan Kader Posyandu Menuju Keluarga Sadar Gizi. Jakarta Direktorat Bina Gizi Kementerian Kesehatan RI.

Sunita, A. 2009. Prinsip dasar ilmu gizi. Gramedia. Jakarta.

Teshome, B. 2009. Magnitude and determinants of stunting in children underfive years of age in food surplus region of Ethiopia: the case of west gojam zone', Ethiopian Journal of Health Development. Ethiopian Public Health Association, 23(2).

Utami, R. P., Probosari, R. M., Fatmawati, U. M. I. 2015. Pengaruh Model Pembelajaran Project Based Learning Berbantu Instagram Terhadap Kemampuan Berpikir Kreatif Siswa Kelas X SMA Negeri 8 Surakarta', Bio-Pedagogi, 4(1), pp. 47-52

Zaki, I., Farida, F., Sari, H. P. 2018. Peningkatan Kapasitas Kader Posyandu Melalui Pelatihan Pemantauan Status Gizi Balita. Jurnal Pengabdian kepada Masyarakat (Indonesian Journal of Community Engagement, 3(2), pp. 169-177. 